\title{
Toxoplasmosis outbreak in sheep in northern-central Paraná, Brazil
}

\section{Surto de toxoplasmose em ovinos na Região Norte Central do Paraná, Brasil}

\author{
Juliana Correa Bernardes ${ }^{1 *}$; Fernanda Pinto-Ferreira2; Luiz Daniel de Barros²; \\ Winni Alves Ladeia3; Marcelle Mareze3; João Pedro Sasse3; Ana Flávia Minutti3; \\ Felippe Danyel Cardoso Martins ${ }^{4}$; João Luis Garcia ${ }^{5}$; Italmar Teodorico Navarro ${ }^{5}$
}

\section{Highlights}

The outbreak reached almost $100 \%$ of the animals.

The outbreak triggered abortion in all pregnant females.

Use of felines as biological rodent control favors the agent cycle.

\begin{abstract}
In this study, we aimed to investigate an outbreak of abortion in a herd of beef sheep on a property in Ivaiporã, north central Paraná, Brazil. A total of 64 blood samples were collected from the sheep, 33 of which were mothers with reports of abortion or stillbirth, and 7 with weak lamb birth. For epidemiological investigation of the parasite, fourteen samples were collected from different sources on the property, six from water, three from soil, one from trough, and four from feed. Indirect immunofluorescence (IFI) analysis and polymerase chain reaction were performed for detecting anti-Toxoplasma gondii antibodies in the sheep and molecular identification of the protozoan in the environment, respectively. The IFI results showed that $95.3 \%$ of the sheep were seropositive for anti-T. gondii antibodies; however, the environmental samples tested negative. During the visit to the property and interview with the owner, free-roaming cats were observed on the property for biological control of rodents that had access to the food deposits. This type of management may have triggered the outbreak, which reinforces the importance of preventive management and veterinary medical monitoring on sheep farms.
\end{abstract}

Key words: Cats. Immunofluorescence. Sheep culture. Abortion. PCR. Toxoplasma gondii.

1 Phd Student in Animal Science, Department of Veterinary Medicine, State University of Londrina, UEL, Londrina, PR, Brazil. E-mail: bernardescj@gmail.com

2 Profs. Drs., Department of Veterinary Medicine, UEL, Londrina, PR, Brazil. E-mail: fernandaferreira@uel.br; luizdanielbarros@gmail.com

${ }^{3}$ Master Degree in Animal Science, Department of Veterinary Medicine, UEL, Londrina, PR, Brazil. E-mail: winnialmarcelle_mareze@hotmail.com; joaosasse@hotmail.com; aninha_minutti@hotmail.com

${ }^{4}$ Phd in Animal Science, Department of Veterinary Medicine, UEL, Londrina, PR, Brazil. E-mail: felippemartins@ hotmail.com

5 Profs. Drs., Department of Veterinary Medicine, UEL, Londrina, PR, Brazil. E-mail: joaoluisgarcia10@gmail.com; italmar@uel.br

* Author for correspondence

Received: Mar. 25, 2020 - Approved: Feb. 02, 2021 


\section{Resumo}

Esse estudo teve como objetivo investigar um surto de aborto em um rebanho de ovinos de corte em uma propriedade de Ivaiporã, região norte central do Paraná, Brasil. Foram coletados 64 amostras de sangue dos ovinos, sendo, que destes, eram 33 matrizes com relato de abortamento ou natimortos, sete com nascimento de descendentes fracos. Para investigação ambiental do parasito, foram coletadas seis amostras de diferentes fontes de água da propriedade, duas de solo, duas de cocho e duas de ração. Realizou-sea imunofluorescência indireta (RIFI) para a detecção de anticorpos anti- Toxoplasma gondii e reação em cadeia da polimerase $(\mathrm{PCR})$ para identificação molecular do protozoário no ambiente. Os resultados da RIFI demostraram que 95,3\% (61/64) dos ovinos eram soropositivos ao T. gondii, contudo, as amostras ambientais foram negativas. Durante a visita à propriedade e entrevista com o proprietário, foi observado presença de gatos de forma livre na propriedade, inclusive com acesso ao depósito de ração para controle biológico de roedores, é possível que esse tipo de manejo tenha desencadeado o surto, o que reforça a importância do manejo preventivo e acompanhamento médico veterinário em propriedades de ovinocultura.

Palavras-chave: Gatos. Imunofluorescência. Ovinocultura. Abortamento. PCR. Toxoplasma gondii.

Toxoplasma gondii is an obligate intracellular protozoan that can infect all warmblooded animals, including humans, and cause toxoplasmosis (Dubey, 2010). The disease is an important cause of reproductive disorders in sheep worldwide and is responsible for economic losses and effects on public health, considering the intake of undercooked infected lambs and milk is an important transmission route to humans (Dubey, 2009; Dubey et al., 2014).

The parasite can be transmitted horizontallyby placenta orvertically byingestion of water and food contaminated with oocysts (Dubey, 2009). In most cases, infection may lead to fetal mummification, abortion, stillbirth, or neonatal death. Clinical signs of infection on reproductive health and their severity are directly related to the stage of pregnancy, tending to more severe clinical manifestations in early pregnancy (Dubey, 2009).

Sheep and goats are one of the most sensitive domesticated animals to T. gondii, and during outbreaks, these animals may serve as sentinels of the parasite in the environment. This study aimed to evaluate an abortion outbreak in a sheep herd from Paraná State, Brazil.

The study was conducted on a sheep farm in the municipality of Ivaiporã, Paraná, which reported reproductive problems in sheep from January to April 2019. Ivaiporã is located at latitude $24^{\circ} 15^{\prime} 0^{\prime \prime} \mathrm{S}$ and longitude $51^{\circ} 40^{\prime} 50^{\prime \prime} \mathrm{W}$, in the central mesoregion of Paraná, with a subtropical climate and Atlantic forest biome. The herd consisted of 64 Santa Inês, Texel, Criola, and crossbred sheep (60 females and 4 males), with a spatial distribution of 5 sheep per hectare, and each with a history of abortion, stillbirth, or weak lamb birth, featuring an outbreak of sheep toxoplasmosis. The property has a semi-intensive breeding system, containing feed and input storage shed, sheep hut, motherhood, feeders, and drinkers with roofs and access to the reservoir, creating and recreating paddocks. 
Environmental samples were collected from soil (3 samples of $50 \mathrm{~g}$ each), water (2 samples of $100 \mathrm{~mL}$ and $10 \mathrm{~L}$ each from mine, reservoir, and pooled water), feed (4 samples of $50 \mathrm{~g}$ each), and sediment from the trough ( 1 sample of $50 \mathrm{~g}$ ). Because of the difficulty in accessing the cats, their feces were not collected. Moreover, aborted fetuses were discarded by the owner, making their investigation impossible. An epidemiological survey was used to obtain information about the individual and health characteristics of the animals and the property.

The blood samples were centrifuged to separate sera, which were subjected to an indirect immunofluorescence assay (IFA) as described by Camargo (1973), using speciesspecific anti-lgG conjugates for sheep (Sigma-Aldrich, San Luis, Missouri, USA) and tachyzoites of the T. gondii strain $\mathrm{RH}$ as antigen. Known positive and negative controls were included for each slide. The collected sera were diluted in a 1:4 ratio until titration values were obtained. Animals with antibody titers $\geq 64$ were considered positive.

Approximately $10 \mathrm{~g}$ of soil, feed, and trough sediment samples were homogenized with $30 \mathrm{~mL}$ of $1 \mathrm{M}$ glycine for $30 \mathrm{~min}$, and kept at rest for 5 min for sedimentation. The supernatant was centrifuged at $1500 \times \mathrm{g}$ for $15 \mathrm{~min}$, purified by sucrose flotation technique, and aliquoted and stored at $-20{ }^{\circ} \mathrm{C}$ for DNA extraction (F. P. Ferreira et al., 2018a).

Water samples from the three different sources were subjected to microbiological and parasitological analyses. The microbiological analysis was performed using the chromogenic substrate technique
(Colilert, Idexx, Westbrook, Maine, USA) using $100 \mathrm{~mL}$ per water sample. For the detection of $T$. gondii in each sample, $1 \mathrm{~L}$ of water was collected in plastic gallons, filtered through a cellulose ester membrane (porosity $=1.2 \mu \mathrm{m}$ ) (Millipore $^{\circledR}$, Billerica, Massachusetts, USA) in a filter support system using a vacuum pump (4 $\mathrm{L} / \mathrm{min}$ ), and eluted in $0.1 \%$ Tween 80 (Franco, Branco, \& Leal, 2012). The samples obtained were concentrated by double centrifugation at $1050 \times \mathrm{g} / 15 \mathrm{~min}$, and aliquoted and stored at $-20^{\circ} \mathrm{C}$ for DNA extraction.

DNA extraction from leukocyte layer and environmental samples was performed using the NucleoSpin Tissue DNA Extraction Kit (Macherey-Nagel, Bethlehem USA), according to the manufacturer's instructions. Environmental samples were previously heated (5 cycles of freezing and thawing at $-80^{\circ} \mathrm{C}$ and $56{ }^{\circ} \mathrm{C}$, respectively). A 529 bp fragment was amplified by polymerase chain reaction (PCR) using the primer pair TOX4 and TOX5 (Homan, Vercammen, De Braekeleer, \& Verschueren, 2000) for the detection of T. gondii DNA. The results were tabulated in Microsoft Excel software for frequency analysis.

On April 15, 2019, a visit was made to the property, and 64 blood samples (for separating the buffy coat and serum) were collected to investigate the probable route of transmission. All samples were seropositive for T. gondii antibody using IFA, with 61 out of 64 samples (95.3\%) having titers greater than 64 . The titer varied between 64 and 4,194,304, as detailed in Table 1. All environmental samples were PCR-negative for T. gondii. 
Table 1

Frequency of seropositive sheep for Toxoplasma gondii according to their titers in Ivaiporã, Paraná, Brazil, 2019

\begin{tabular}{|cc|}
\hline Titration & Frequency $\%(\mathrm{n} / \mathrm{N})$ \\
\hline $16^{*}$ & $4.6 \%(3 / 64)$ \\
64 & $3.1 \%(2 / 64)$ \\
256 & $9.4 \%(6 / 64)$ \\
1,024 & $15.6 \%(10 / 64)$ \\
4,096 & $21.9 \%(14 / 64)$ \\
16,384 & $4.6 \%(3 / 64)$ \\
65,536 & $12.5 \%(8 / 64)$ \\
262,144 & $9.4 \%(6 / 64)$ \\
$1,048,576$ & $12.5 \%(8 / 64)$ \\
$4,194,304$ & $6.3 \%(4 / 64)$ \\
\hline
\end{tabular}

*The samples were considered positive when the titration was equal to or greater than 64 .

The presence of rodents was reported in the feed deposit, corral, and residence. To control them, 5 domestic cats ( 1 adult and 4 young), which had free access to the entire property, were kept. Water for animal and human consumption came from a protected mine. Sheep were reared only for meat and animal slaughter was carried out on the property only for the consumption of the resident family. The breeding facilities were cleaned monthly, and assistance by a private veterinarian was sporadic.

The epidemiological survey helped to trace an investigative link between obtaining felines for biological control of rodents on the property and the outbreak of abortions in sheep. According to Frenkel, Ruiz, and Chinchilla, (1975), the link between these two species in rural properties is of great importance in the epidemiology of T. gondii. Large quantities of oocysts are released through cat feces (definitive hosts) that can remain viable in the environment for years. In an outbreak scenario, cats can get infected through predation on rodents or consumption of contaminated food and water. Sheep can get infected through contaminated feed, fodder, or water with oocysts. According to Santos et al. (2010), free access of the internal and external facilities of rural properties to cats and rats can increase the epidemiological risks of $T$. gondii.

In vertical transmission, matrices infected during pregnancy can transmit the disease to the fetuses (Dubey et al., 2014). According to the owner, approximately $82.5 \%$ (33 out of 40) of pregnant mothers had abortions or conceived stillborn animals, 3 of which occurred after visiting the property. In a study conducted in South Dakota, USA, 11 of 30 aborted lambs (36.67\%) were found to be seropositive for $T$. gondii through immunodiagnosis (Dubey \& Kirkbride 1989). Gabardo, Oliveira, Ecco and Guedes (2013) 
described an outbreak in Minas Gerais, Brazil, in which $40 \%$ (40 out of 100 ) of ewes either aborted or gave birth to stillborn offspring. The authors conducted a serological survey for toxoplasmosis, neosporosis, brucellosis, and leptospirosis, finding only seropositive animals for T.gondii. The immunohistochemical analysis of the brain of an aborted fetus demonstrated differentiation of lesions compatible with Neospora caninum and $T$. gondii to confirm the diagnosis. According to the epidemiological survey, cats were present on the property.

The acute infection justifies the high titers in seroreagents in this outbreak, in which 54 of the 61 samples considered positive $(84.88 \%)$ obtained titers $\geq 4,096$, of which $7.40 \%$ (4 out of 54 ) reached 4,194,304. Furthermore, J. M. Ferreira et al. (2018b) reported an outbreak of toxoplasmosis in a goat herd in the municipality of Arapoti, Paraná, Brazil, in which $76.53 \%$ (137 out of 179) of the animals were seropositive for $T$. gondii with significant prevalence; however, majority of the animals had titers $\leq 4,096$. It is noteworthy that sheep and goats have similar habits and management such as ingestion of low pastures closer to the soil, as well as greater sensitivity to the parasite. In this study the relationship between high titers may have occurred owing to the immune responses from these species. According to Dubey, Emond, Desmonts and Anderson (1987), production of immunoglobulin IgM appears in the initial phase of the infection and is characterized in the acute phase of the disease, followed by immunoglobulin IgG, which appears in the chronic phase. IgG titers remain constant or spike if there is an infection, decreasing or even disappearing during the months after infection.
The appearance of clinical signs after infection can take days or months, and exposed animals can be symptomatic or asymptomatic. According to the owner, abortion in sheep occurred days after the acquisition of the 5 cats for biological control of rodents. Chiebao et al. (2019) conducted an experimental study in São Paulo, in which groups of sheep were challenged with different strains of T. gondii, and the first clinical signs were observed between days 7 and 9 after challenge.

Domestic cats had access to the entire property, including the feed storage, where mice were present. It is possible that the feces of these cats contaminated the feed of the sheep, as previously reported by J. M. Ferreira et al. (2018b). However, no environmental samples tested positive for T. gondii. Therefore, laboratory results must be evaluated together with epidemiological analyses, since negativity does not exclude the possibility of the presence of $T$. gondii oocysts. It is important to understand that the diagnostic techniques for environmental sample assays have low sensitivity, because these samples have DNA amplification inhibitors, and difficulty in parasite recovery is caused by dilution of protozoa in environments that require the collection of large volumes of samples, associated with a variety of concentration techniques. Another important point is the time elapsed between the appearance of first clinical signs in the herd and the collection of samples, which is usually extended (Franco et al., 2012).

The sheep are raised and slaughtered on the property for consumption by their owner. In addition to the zoonotic risks associated with the consumption of this meat, the disease can trigger economic losses for the producer, which reinforces the need for veterinary medical monitoring and the development of 
good sheep management practices. According to Movassaghi, Rassouli, Fazaeli and SalimiBejestani (2016), toxoplasmosis has been widely studied owing to its importance for human health. The research group estimated that the economic loss in sheep farming caused by abortion is US $\$ 10,000 /$ month. In association with the risks of consuming cured or rare meat from sheep, Belluco, Simonato, Mancin, Pietrobelli and Ricci. (2018), through a systematic review, pointed out an odds ratio of 3.85 (1.85-8.00) for the risks of infection through inappropriate consumption.

Although various studies have described outbreaks with focus on local epidemiology, it is still important to characterize the epidemiology of toxoplasmosis in herds and mark zoonotic patterns of transmission. This knowledge is essential to understand the necessary preventive measures and where they are required to be effective in controlling the disease in affected populations.

The relationship between research and extension is necessary for the re-education of habits and in the management of sheep farms. Few studies focus on epidemiological triad description in sheep (Movassaghi et al., 2016; Plant, Richardson, \& Moyle, 1974; Zedda et al., 2010). Most of the studies on toxoplasmosis in sheep have focused on diagnoses, prevalence, clinical observations, correlation with other species, transmission routes, and zoonosis, which may or may not be related to the consequences of outbreaks.

The results of this investigation confirmed the presence of antibodies against T. gondii in sheep from the outbreak. High antibody titers confirmed the relationship between acute infection and the occurrence of abortion in more than half of the pregnant females in the herd. The presence of cats on the property with the aim of controlling the rodent population demonstrates the lack of sanitary education in these small-farm owners and the necessity of technical assistance to prevent the disease in animals and humans.

\section{Acknowledgments}

The authors are grateful to the Coordinating Body for the Improvement of Higher Education Personnel (CAPES) for their fellowships.

\section{References}

Belluco, S., Simonato, G., Mancin, M., Pietrobelli, M., \& Ricci, A. (2018). Toxoplasma gondii infection and food consumption: a systematic review and meta-analysis of case-controlled studies. Critical Reviews in Food Science and Nutrition., 58(18), 3085-3096. doi: 10.1080/10408398.2017.1352563

Camargo, M. E. (1973). Introdução às técnicas de imunofluorescência. Revista Brasileira de Patologia Clínica, 10(4), 143-171.

Chiebao, D. P., Pena, H. F., Passarelli, D., Santín, T., Pulz, L. H., Strefezzi, R. F.,... Soares, R. M. (2019). Congenital transmission of Toxoplasma gondii after experimental reinfection with brazilian typical strains in chronically infected sheep. Frontiers Veterinary Sciense, 6(93), 1-11. doi: 10.3389/fvets.2019. 00093

Dubey, J. P. (2009). Toxoplasmosis in sheep-the last 20 years. Veterinary Parasitology, 163(1-2), 1-14 doi: 10.1016/j. vetpar.2009.02.026 
Dubey, J. P. (2010). Toxoplasmosis of animals and humans (2nd ed.). Maryland, USA: CRC Press.

Dubey, J. P., Emond, J. P., Desmonts, G., \& Anderson, W. R. (1987). Serodiagnosis of postnatally and prenatally induced toxoplasmosis in sheep. American Journal of Veterinary Research (48), 1239-1243. Retrieverd from https://pubmed.ncbi.nlm. nih.gov/3631714/

Dubey, J. P., \& Kirkbride, C. A. (1989). Economic and public health considerations of congenital toxoplasmosis in lambs. Journal of the American Veterinary Medical Association, 195(12), 1715-1716. Retrieved from http://europepmc.org/ abstract/MED/2599957

Dubey, J. P., Verma, S. K., Ferreira, L. R., Oliveira, S., Cassineli, A. B., Ying, Y.,... Jones, J. L. (2014). Detection and survival of Toxoplasma gondii in milk and cheese from experimentally infected goats. Journal of Food Protection, 77(10), 1747-1753. doi: 10.4315/0362-028X.JFP-14-167

Ferreira, F. P., Caldart, E. T., Freire, R. L., Freitas, F. M. de, Miura, A. C., Mareze, M.,... Navarro, I. T. (2018a). The effect of water source and soil supplementation on parasite contamination in organic vegetable gardens. Brazilian Journal of Veterinary Parasitology, 27(3), 327-337. doi: 10.1590/ s1984-296120180050

Ferreira, J. M., Neto, Ferreira, F. P., Miura, A. C., Almeida, J. C. de, Martins, F. D. C., Souza, M. de,... Navarro, I. T. (2018b). An outbreak of caprine toxoplasmosis - investigation and case report. Ciência Rural, 48(5). doi: 10.1590/0103-8478cr20170790
Franco, R. M., Branco, N., \& Leal, D. A. G. (2012). Parasitologia ambiental: métodos de concentração e detecção de Cryptosporidium spp. e Giardia spp. em amostras de água. Revista de Patologia Tropical, 41(2), 119-135. doi: 10.5216/rpt. v41i2.19320

Frenkel, J. K., Ruiz, A., \& Chinchilla, M. (1975). Soil survival of Toxoplasma oocysts in Kansas and Costa Rica. American Journal of Tropical Medicine and Hygiene, 24(3), 439-443. doi: 10.4269/ajtmh.1975. 24.439

Gabardo, M. P., Oliveira, J. S. V., Ecco, R., \& Guedes, R. M. C. (2013). Outbreak of ovine abortion by toxoplasmosis in southeastern Brazil. Brazilian Journal of Veterinary Pathology., 6(1), 37-41. doi: 10. 1590/S0100-736X2011001100001

Homan, W. L., Vercammen, M., De Braekeleer, J., \&Verschueren, H. (2000). Identification of a 200- to 300-fold repetitive 529 bp DNA fragment in Toxoplasma gondii, and its use for diagnostic and quantitative PCR. International Journal for Parasitology, $30(1)$, 69-75. doi: 10.1016/s00207519(99)00170-8

Movassaghi, A. R., Rassouli, M., Fazaeli, A., \& Salimi-Bejestani, M. R. (2016). Outbreak of ovine congenital toxoplasmosis in Iran, confirmed by different diagnostic methods. Journal of Parasitic Diseases, 40(1), 152-156. doi: 10.1007/s12639014-0467-x

Plant, J. W., Richardson, N., \& Moyle, G. G. (1974). Toxoplasma infection and abortion in sheep associated with feeding of grain contaminated with cat faeces. Australian Veterinary Journal, 50(1), 19-21. doi: 10.1111/j.1751-0813.1974.tb09365.x 
Santos, T. R. dos, Nunes, C. M., Rui Luvizotto, M. C., Moura, A. B. de, Zanetti Lopes, W. D., Costa, A. J. da, \& Saraiva Bresciani, K. D. (2010). Detection of Toxoplasma gondii oocysts in environmental samples from public schools. Veterinary Parasitology, 171(1-2), 53-57. doi: 10.1016/j.vetpar.20 10.02 .045
Zedda, M. T., Rolesu, S., Pau, S., Rosati, I., Ledda, S., Satta, G.,... Masala, G. (2010). Epidemiological study of Toxoplasma gondii infection in ovine breeding. Zoonoses and Public Health, 57(7-8), e1028. doi: 10.1111/j.1863-2378.2009.01292.x 